\title{
Customer Satisfactions on Islamic Banking System
}

\author{
Noradiva Hamzah, Noriah Mohd Ishak, and Nurul Izzah Mohd Nor
}

\begin{abstract}
Service quality has been regarded as one of the key factor to compete in the banking industry. Therefore, in order to be competitive it is vital for the banks to fulfill customers' satisfactions. The objective of this study is to investigate the relationship between customer satisfaction and the service quality of Islamic banks in Malaysia. A survey was conducted in this study. The study revealed that there is a positive relationship between customer satisfaction and constructs of service quality such as personnel of the banks, image of the banks, services offered by the banks and the accessibility of the banks.
\end{abstract}

Index Terms-Customer satisfactions, survey, service quality, Islamic banks in Malaysia.

\section{INTRODUCTION}

Customers' satisfaction is vital in determining the success of an organization. High performance and fully satisfied customer will be the mouth extensions to promote the organization. This eventually will assist the organization to stand strong in the market and be more competitive. According to Haque et al., [1], over the last three decades, the emergence of strong Islamic movement has created a renewed interest in Islamic economics. It is where the Islamic interest-free banking started to fame. The Islamic banking system has gained momentum globally and is not restricted only to Islamic banks. The consequences of this shifts is that the Islamic banks operating in Islamic countries face strong competition from Islamic and conventional banks. They offer similar products and services. Hence, when competition intensifies, customers' perceptions will determine the competitiveness and success of the banks.

Naser et al., [2] argued that Islamic banks are facing a strong polemic of customers' opinion towards their services and performances. Nowadays, customers have become more knowledgeable and educated. Hence, banks are better aware about the satisfaction of their customers regarding services and products being offered. Besides, demand for excellent quality products and services are expecting with the increase in customer buying capacity. Therefore, banks need to continuously improve the quality of products and services offered to their customers. The objective of this study is to investigate the relationship between customers' satisfaction and services quality provided by Islamic banks in Malaysia.

Manuscript received August 25, 2013; revised November 7, 2013.

Noradiva Hamzah is with the Universiti Kebangsaan Malaysia (e-mail: adibiez@yahoo.com.sg).

\section{LITERATURE REVIEW}

\section{A. Customers' Satisfaction}

Customer satisfaction represents a modern approach for quality in organizations that serves the development of a truly customer-focused management and culture. An immediate, meaningful and objective feedback about clients' preference and expectations are ways to measure customers' satisfaction [3]. Customers' satisfaction refer to customer's rating of the is an output, resulting from the customer's pre-purchase comparison of expected performance with perceived actual performance [4].

Customer satisfaction was driven by factors such as service quality, location, competitiveness of the bank's interest rates and employees' skill [5]. Meanwhile Erol et al., [6] identified factors such as location, friend's recommendations, bank reputations; availability of credit, competitive interest rates, friendliness of bank staff, service charges, adequate banking hours, availability of ATM, special services and the quality of services on checking accounts will affect the customer satisfaction. Mihelis et al., [3], also argue that hierarchical structure of customers' satisfaction dimensions can be divided into four main groups; personnel of the banks, image of the banks, services offered and accessibility. Personnel of the bank include skills, knowledge, responsiveness and friendliness communication. Meanwhile image of the banks consists of the credibility, technology excellence, and ability to satisfy future needs. The services offered contains of the appearance of the bank, waiting time, service processes and adequate information given. The accessibility comprises of the network expansion, branches location, service system and the location of the bank.

\section{B. Personnel and Customer Satisfaction}

Islamic banks appear to be predominantly a combination of Islamic and financial reputation and quality service offered by the bank. Therefore, Islamic banks must have good public relations in order to boost their reputation simultaneously to foster good customer-employee relations in order to attract customers [7]. Competent personnel of the bankers coupled with friendly and courteous values to be the most important criteria in patronizing customers for Islamic banks. According to Abbas et al., [8], where the staff factor is one of the most important factors that customers use to select an Islamic bank. They argued that, incompetence and lack of courtesy of the bank's personnel, was the major reason why customers turn away from Islamic finance. Indeed, sufficient knowledge in various Islamic banking instruments compounded with other relevant aspects such as ethics, professionalism, duties and responsibilities towards customers and organizations will enhance efficiency and 
smooth-running of Islamic banking. Adequate personnel training also boosts the quality of Islamic banking staff which eventually may influence and attract more customers into choosing Islamic financing as their preferred choice.

Turnbull and Gibbs [9] found out that corporate customers nominate the quality of services offered is also an important factor in obtaining their satisfaction, which include quality of staff, bank manager's attitude, and price of service. Haron et al., [10] sought to establish the selection criteria used by Muslim customers were the provision of a fast and efficient service, the speed of transaction, and friendly bank personnel. On the basis of this, Tan and Chua [11] argued that in an Oriental culture, customers desired to have a more intimate and close interaction with the bank personnel. Therefore, it is important to determine whether is there any association between personnel of the bankers such as skills and knowledge, responsiveness, friendliness communication and customers' collaboration, with the satisfaction of customer. In this study, personnel of the bankers are predicted to have a significant impact on the customer satisfaction of a bank.

\section{Image and Customer Satisfaction}

Previous studies have discovered that one of the most important criteria considered by the customers is bank's reputation and image [12]; [13]; and [2]. For example, they would only switch their banks if the new banks were able to show that the quality of its products and services were more superior that others [14]. Meanwhile, study conducted by Yousuff and Azurah [15], revealed that bank's name and reputation will strongly affect one to select a bank to deal with. In this study, image of the bank is predicted to have a significant impact on the customer satisfaction of a bank.

\section{Services Offered and Customer Satisfaction}

According to Haque et al., [1], the provision of high standard of service quality may manage to increase customer satisfaction. Previous studies found that there are positive values which indicate a strong correlation and significant relationship between customers' satisfaction and service quality [12]; [13]; [2]; [16]; has conducted a study in Turkey where they found that the core element of customer satisfaction in Turkish banking industry is the service quality. The quality of services includes factors like treating customers with courtesy and respect, staff ability to convey trust and confidence, efficiency and effectiveness in handling any transaction, and knowledgeable and preparedness in providing solutions and answers concerning Islamic bank's products and services.

\section{E. Accessibility of the Bank and Customer Satisfaction}

Factors such as a convenient location, accessibility of the banks, reward extended by the banks have been identified as critical factors influencing the choice of a bank by customer [11], [13]. The availability of service and social, as well as religious perspective at higher level could make Islamic Banking easier and comfortable. Thus, the customers' satisfaction can be obtained at high rate [1]. Dusuki and Abdullah, [7], found that another important factor influencing stakeholder banking selection criteria and their satisfactory is relates to location and convenience such as available parking space and interior comfort.

\section{RESEARCH FRAMEWORK}

The theoretical framework of this study is adapted from [3]. This framework describes that personnel, image, services and accessibility of a bank have association to the customers' satisfaction. The conceptual framework is illustrates as follow:

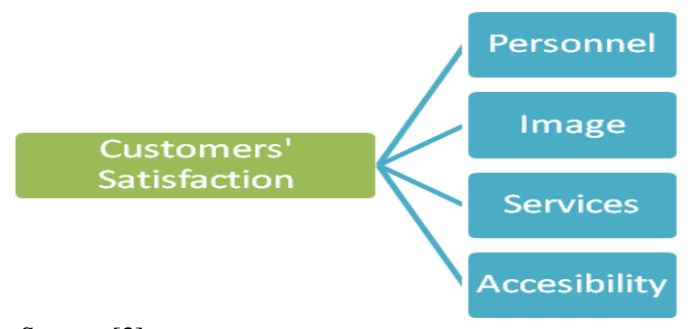

Source: [3]

Fig. 1. Research framework.

The first variable tested is personnel of the bank which includes factors such as skills and knowledge, responsiveness, friendliness communication and collaboration with customers. The second variable is the image of the bank which consists of the credibility, technology excellence, and ability to satisfy future needs. While the third is the services offered, which contains of the appearance of the store, waiting time, service processes and adequate information given. The last variable is the accessibility which means the network expansion, branches location, and the service system of banks.

The hypotheses tested are: $\mathrm{H}_{1}$ : Personnel of the bankers has significant impact on customer satisfaction; $\mathrm{H}_{2}$ : Image of the bank has significant impact on customer satisfaction; $\mathrm{H}_{3}$ : The services offered has significant impact on customer satisfaction; $\mathrm{H}_{4}$ : Accessibility of the bank has significant impact on customer satisfaction

\section{Methodology}

This study used a survey approach and questionnaire was adapted from [3]. There were three sections in the questionnaire. First part focused on the general information of respondents that include social demographic variables such as gender, age group and which account holder they were. The second part includes the factors that are predicted to affect the customer satisfaction which consists of: level of satisfaction towards the personnel of the bankers; level of satisfaction towards the image of the bank; level of satisfaction towards the services offered by the banks, and level of satisfaction towards the accessibility of the banks The third part conveyed the global satisfaction of customers toward the bank. In both second and third sections, the respondents were asked to indicate, on a three-point Likert-type scale, ranging from "very unsatisfied" to "very satisfied", the factors they perceive to determine their satisfaction towards the service quality offered by both Islamic banks.

\section{FINDINGS AND DISCUSSION}

The correlation test was conducted to determine the 
relationship between the service quality offered (personnel of the bankers, image of the banks, services offered by the banks and the accessibility of the banks) with the customer satisfaction.

TABLE I: CORRELATION TEST BETWEEN SERVICE QUALITY FACTORS AND CUSTOMER SATISFACTION

\begin{tabular}{|c|c|c|c|c|c|c|c|c|c|c|}
\hline & & & $\begin{array}{c}\text { MEAN. } \\
\text { PERSON } \\
\text { NEL }\end{array}$ & F & $\begin{array}{l}\text { MEAN. } \\
\text { IMAGE }\end{array}$ & F & $\begin{array}{c}\text { MEAN. } \\
\text { SERVICE }\end{array}$ & $\mathrm{F}$ & $\begin{array}{c}\text { MEAN. } \\
\text { ACCESSIB } \\
\text { ILITY }\end{array}$ & F \\
\hline \multirow[t]{6}{*}{ Spearman's rho } & \multirow[t]{3}{*}{ MEAN } & Correlation Coefficient & 1.000 & $.465^{\circ}$ & 1.000 & $.526^{\circ}$ & 1.000 & $.396^{\circ}$ & 1.000 & $.460^{\circ}$ \\
\hline & & Sig. (2-tailed) & . & .000 & . & .000 & . & .000 & . & .000 \\
\hline & & $\mathrm{N}$ & 162 & 161 & 162 & 161 & 162 & 161 & 162 & 161 \\
\hline & \multirow[t]{3}{*}{ F } & Correlation Coefficient & $.465^{*}$ & 1.000 & $.526^{*}$ & 1.000 & $.396^{\circ}$ & 1.000 & $.460^{\circ}$ & 1.000 \\
\hline & & Sig. (2-tailed) & .000 & & .000 & & .000 & . & .000 & . \\
\hline & & $\mathrm{N}$ & 161 & 161 & 161 & 161 & 161 & 161 & 161 & 161 \\
\hline
\end{tabular}

**. Correlation is significant at the 0.01 level (2-tailed).

From Table I above, it can be seen that the $r$ value for personnel is 0.465 . It shows that there is a positive correlation between the customer satisfaction and the personnel of the bankers. Hence, it can be concluded that the personnel of the bankers are significant to the level of customer satisfaction of Islamic banks. This shows that the personnel of the bankers are significant to the customer satisfaction. Thus, the hypothesis predicted earlier is true and therefore accepted. The finding was corresponds to the study of [8], where the staff factor is one of the most important factors that customers use to select an Islamic bank that leads to customer satisfaction.

Incompetence and lack of courtesy of the bank's personnel, was the major reason why customers turn away from Islamic finance. Indeed, sufficient knowledge in various Islamic banking instruments compounded with other relevant aspects such as ethics, professionalism, duties and responsibilities towards customers and organizations will enhance efficiency and smooth-running of Islamic banking. Adequate personnel training also boosts the quality of Islamic banking staff which eventually may influence and attract more customers into choosing Islamic financing as their preferred choice. Another study conducted by [3], also proved that the values practised by the bankers such as caring employees will attract and satisfy customers more as employees play an important role in company-customer interaction.

For image, the $r$ value is 0.526 . This also indicates that there is a positive correlation between the level of customer satisfaction and the image of the banks. Thus, the hypothesis predicted earlier is true and consequently accepted. This finding is tallies with a study conducted by [12] that has discovered bank's reputation and image to be one of the most important criteria considered by the customers. It is also supported firmly by other researches such as are [13] and [2]. As also stated by [13], another strategy to induce customer satisfaction is to maintain the image and reputation as well as protecting customers' confidentiality. This type of image will keep the bond of loyalty keep strong therefore the satisfaction will be maintained.

The $r$ value for service is 0.396 . It shows that there is a positive correlation between the level of customer satisfaction and the services offered by the bank. Therefore, it indicates that the services offered by the bank are significant to the level of customer satisfaction of Islamic banks. Thus, the hypothesis suggested earlier is true and hence accepted. This finding is identical to the study conducted by [1], where the provision of high standard of service quality may manage to increase customer satisfaction. Their study found that there are positive values which indicate a correlation and significant relationship between customers' satisfaction and service quality. While [16], has conducted a study in Turkey where they found that the core element of customer satisfaction in Turkish banking industry is said to be the service quality, in the relationship between the service quality and customer satisfaction.

The quality of services includes factors like treating customers with courtesy and respect, staff ability to convey trust and confidence, efficiency and effectiveness in handling any transaction, and knowledgeable and preparedness in providing solutions and answers concerning Islamic bank's products and services. Another study that obtained the same result as the finding in this study is [17], where they found out that service problems and the bank's service recovery ability have a major impact on customer satisfaction and will create an intention for the customer to switch to another bank. While [18], in their study had found that there is a positive and significant relationship between customer satisfaction and service quality.

The $r$ value for accessibility factor is 0.460 . It shows that there is a positive correlation between the customer satisfaction and the accessibility of the bankers. This study shows that the accessibility of the bank is significant to the level of customer satisfaction of Islamic banks. Thus, the hypothesis postulated earlier is true and therefore accepted. This finding matched with [1], where they figured out that the availability of service and social, as well as religious perspective at higher level could make Islamic Banking easier and comfortable.

The regression test is also conducted to examine the percentage of the customer satisfaction that can be predicted by the service quality offered by the Islamic banks which consist of personnel of the bankers, image of the banks, services offered by the banks and the accessibility of the banks. Based on the analysis conducted, it shows that $19 \%$ of 
customers' satisfaction can be predicted by personnel of the bankers, $25 \%$ of customers' satisfaction can be predicted by image of the bank, $6 \%$ of customers' satisfaction can be predicted by services offered by the bank, and $16 \%$ of customers' satisfaction can be predicted by accessibility of the bank.

\section{CONCLUSION}

As obtained in the result, all of the hypothesises postulated are accepted which resembles that the service quality of the banks, comprises of personnel of the bankers, image of the banks, services offered by the banks and the accessibility of the banks are significant to the customer satisfaction of Islamic banks. Therefore, several steps should be taken by the Islamic banks to enhance their service quality to stay marketed, maintain a premium position at the top and to compete with conventional banks that provide Islamic banking as well. Some blueprints that should be taken by the Islamic banks are to invest in training and development of human resource as well as to establish a motivating system for employees. This is for the improvement of the personnel of the bankers for a better handle of their customers and efficiently handling customers' problem besides fulfilling customers' demand.

Other than that, Islamic banks can build a strategy to improve their image and reputation of the banks. This is because image of the bank plays the most major determinant for the customer satisfaction in this study. So as the reputation and the technological excellence is rallied up, the bank should ensure the retention of existing customers and attract more new customers that are satisfied with the bank. As coined by Yousuff and Azurah [15], where that bank's name and reputation will strongly affect one to select a bank to deal with that will consequently satisfy the customers. The reputation and image factor are evidenced as one of the important criteria in the banking selection decision that simultaneously lead to customer satisfaction.

As service offered by the bank will affect customer satisfaction as well, an interior benchmarking system can be established based on the results obtained. Whichever franchise of Islamic banks that acquire high customer satisfaction should become a benchmark to be exampled by other branches of the bank and vice versa. As in this study, the scope of the franchise only covered Islamic banks around Klang Valley and Putrajaya, further studies are suggested to broaden up the scope and area to gather more information about the customer satisfaction and its relation with service quality. Islamic banks should also provide a wide range of information about services offered and adequate information to satisfy the customers' needs. This study also allow Islamic banks to determine the weakness and the strong points of the bank therefore could predict the effectiveness of marketing plans and the room for improvement can always be fulfilled. As economic progression never sleeps, and as Islamic financial institutions are not regarded as institution carrying financial activities for Muslims only but more specifically, Islamic banks are carrying business that is trying to overcome the whole banking industry fulfilling the needs of the world economy, customer satisfaction should be prioritized and the needs should always be contented. Hence, further researches are recommended to do a comparison of customer satisfaction and the service quality offered by both Islamic banks and conventional banks that provide Islamic Banking System as well.

\section{REFERENCES}

[1] A. Haque, J. Osman, and A. Z. Ismail, "Factor influence selection of islamic banking: A study of malaysian customer preferences," American Journal of Applied Sciences, vol. 6, no. 5, pp. 922-928, 2009.

[2] K. Naser, A. Jamal, and K. A. Khatib, "Islamic banking: A study of customer satisfaction and preference in Jordan," International Journal of Bank Marketing, vol. 17, no. 3. pp. 135-151, 1999.

[3] G. Mihelis, E. Grigoroudis, and Y. Siskos, "Customer satisfaction measurement in the private bank sector," European Journal of Operational Research, vol. 130, pp. 347-360, 2001.

[4] G. A. Churchill and S. Carol, "An investigation into the determinants of customer satisfaction," Journal of Marketing Research, vol. 19, pp. 481-504, Nov. 1982.

[5] M. N. Akhtar, A. I. Hunjra, S. W. Akbar, K. U. Rehman, and G. S. K. Niazi, "Relationship between customer satisfaction and service quality of Islamic bank," World Applied Sciences Journal, vol. 13, no. 3, pp. 453-459, 2011.

[6] C. Erol, E. Kaynak, and R. E. Bdour, "Conventional and Islamic bank: Patronage behaviour of Jordanian customers," International Journal of Bank Marketing, vol. 8, no. 5, pp. 25-35, 1990.

[7] A. W. Dusuki and N. I. Abdullah, "Why do Malaysians customers patronize Islamic banks?" International Journal of Bank Marketing, vol. 25, no. 3, pp. 142-160, 2007.

[8] S. Z. M. Abbas, M. A. A. Hamid, H. Joher, and S. Ismail, "Factors that determine consumers' choice in selecting Islamic financing products," in Proc. International Islamic Banking Conference, Prato, Bank Negara Malaysia, Annual Report, 2003.

[9] P. W. Turnbull and M. J. Gibbs, "The selections of banks and banking services among corporate customers in South Africa", International Journal of Bank Marketing, vol. 7, no. 5, pp. 36-39, 1989.

[10] S. Haron, N. Ahmad, and S. Planisek, "Bank patronage factors of Muslim and non-Muslim customers," International Journal of Bank Marketing, vol. 12, no. 1, pp. 32-40, 1994.

[11] C. T. Tan and C. Chua, "Intention, attitude and social influence in bank selection: A study in an oriental culture," International Journal of Bank Marketing, vol. 4, no. 3, pp. 43-53, 1986.

[12] C. Erol and R. E. Bdour, "Attitude, behaviour and patronage factors of bank customers towards Islamic banks," International Journal of Bank Marketing, vol. 7, no. 6, pp. 31-37, 1989.

[13] S. A. Metawa and M. Almossawi, "Banking behaviour of Islamic bank customers: perspectives and implications," International Journal of Bank Marketing, vol.16, no.7, pp. 299-313, 1998.

[14] A. K. K. Chan and V. S. M. Ma, "Corporate banking behavior: A survey in Hong Kong," International Journal of Banking Marketing, vol. 8, no. 2, pp. 25-31, 1990.

[15] R. Yousuff and K. N. Azurah, "Selection factors of Islamic banking between bank Islam Malaysia berhad and conventional banks amongst public servants in Kotakinabalu," in Proc. Annual Conference on Malaysian Finance Associations, May 20006, pp. 315-329.

[16] U. Yavas, Z. Bilgin, and D. J. Shemwell, "Service quality in the banking sector in an emerging economy: A consumer survey," International Journal of Bank Marketing, vol. 15, no. 6, pp. 217-223, 1997.

[17] T. Levesque and G. H. G. McDougall, "Determinants of customer satisfaction in retail banking," International Journal of Bank Marketing, vol. 14, pp. 12-20, 1996.

[18] J. Cronin and S. A. Taylor, "Measuring service quality: A re-examination and extension," Journal of Marketing, vol. 56, pp. 55-68, 1992.

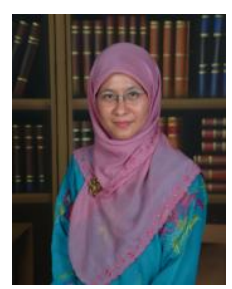

Noradiva Hamzah holds a Bachelor of Accounting from Universiti Kebangsaan Malaysia, an MA from New CastleiUpon tyne, UK and a Ph.D from University of Malaya. Her research areas of interest include Intellectual Capital reporting, Intellectual Capital Management, Knowledge Management, Offshore Accounting Outsourcing and Islamic Financial reporting. 


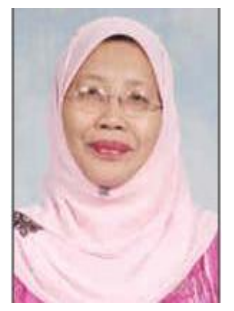

Noriah Mohd Ishak is the permatapintar director, Universiti Kebangsaan Malaysia. Her research areas of interest include Emotional Intelligent Test (EQ) and Intelligence Quotient (IQ). She received her degree in BscEducation from Universiti Kebangsaan Malaysia, Master in Education also from Universiti Kebangsaan Malaysia and $\mathrm{PhD}$. From Western Michigan University, USA.

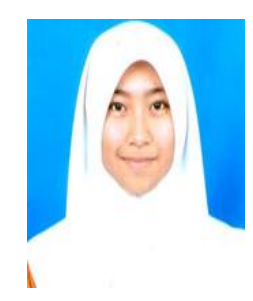

Nurul Izzah Mohd Nor was a ASASI pintar (pre-university program) student at Pusat Permatapintar Negara, Universiti Kebangsaan Malaysia. Currently she is pursuing her degree at Faculty of Economics and Management, Universiti Kebangsaan Malaysia. 